\title{
PATTERNS OF MASCULINITIES IN DISCOURSE OF REPORTS ASSESSING CONDITION OF POLISH STARTUPS ORGANISATIONS
}

\author{
EDYTA TOBIASIEWICZ ${ }^{1}$ \\ ${ }^{1}$ Jagiellonian University in Cracow, Faculty of Philosophy, Institute of Sociology, ul. Gołębia 24, \\ 310-007 Kraków, Poland. ORCID: 0000-0002-6171-773X, Email: edyta.tobiasiewicz@doctoral.uj.edu.pl
}

ABSTRACT: The purpose of this article is presentation patterns of masculinities, present in startup discourse, which as professional structures with new management models, belonging to the knowledge-based economy model, and are an example of organizations typical of the information society. The method used in the research was critical discourse analysis, and the sample included five reports published by (the largest institution reporting on the condition of the Polish startup ecosystem) the Startup Poland Foundation from 2015-2019. This paper is also an attempt to apply the heuristic framework of integrative theories of gender to interpret the results of the research, from innovative organizational structures. The research results show that the symbolic dimension of startups is a significantly gendered space. The meanings attributed to working in a startup are strongly related to hegemonic masculinity (fight, win, economic domination, expansion, risk taking), which is embodied by a few actors (e.g. owners of Facebook, Amazon). At the same time, the specificity of hegemonic masculinity is redefined in this context (e.g. physical strength gives way to intellectual proficiency). There are also numerous appeals to practices in the startup discourse which could be associated with other gender constructs (cooperation, consent to make mistakes or creating wide networks of social relations).

KEYWORDS: patterns of masculinities, gender, critical discourse analysis, integrative theories of gender, startup, gendered organizations 


\section{INTRODUCTION}

The purpose of this paper is to present the results of a critical discourse analysis,

1 aimed at examining what patterns of masculinities are present in reports informing about the situation of the Polish startups organizations (and all startups ecosystem), and by for what are characteristized this patterns.

Research focusing on issue of gender in various organizations has been intensively developed since the 70s of the 20 $0^{\text {th }}$ century (see Kanter 1977; Epstein 1988; Williams et al. 1992; Acker 1990, 1992; Connell 2006; Pacholok 2009; Siemieńska 2019). The vast majority of available studies focuses on the situation of broadly understood cultural femininity (see Leszczyńska 2016; Bird \& Rhoton 2011; Martin 2003; Alvesson \& Billing 1992) interpreted intersectionally, and to a lesser extent masculinity, the initial analyses of which could be considered a "side effect" of research on femininity and women. However, what is especially important considering the purpose of this article, these analyses are usually embedded in the context of highly formalized organizations, with classical management patterns, hierarchical structure, and specialized operating strategies. The analysis of masculinities patterns, which I undertake in my article, places gender in the area of startup organizations and supporting institutions (like foundations, universities, mentors) that are characterized by a completely different specificity: non-traditional and non-hierarchical management models, a relatively short period of developing your own business, undefined and stabilizing organizational structures, oriented towards generating innovative solutions that can be spread on the international arena, and also towards achieving high profits, using advanced technologies (Kulej 2018).

The structure of the article is as follows. Part one provides an overview of research focusing on gender and organizational issues (especially high-tech), as well as key findings from empirical research. The second part is devoted to the discussion of the most important theoretical concepts relating to patterns of masculinities, as well as those relating to the subdiscipline of gendered organizations. The third part presents the methodology of the conducted research. The remaining two parts present the results of the analyses and place the research results in the theoretical and empirical context.

\section{GENDER IN THE CONTEXT OF TECHNOLOGICAL STARTUPS}

An analysis of the literature on gender and startups proves that these organizations, along with their institutional environment (called the startup ecosystem), are not gender neutral. On the contrary, gender is a differentiating category for many dimensions of startup activities.

Numerous published statistical analyses allowed to illustrate the percentage of women and men in startups. The results clearly indicate the overrepresentation of men and the underrepresentation of women both among the founders of technology startups, but also investors supporting startups at early and later stages of development, regardless of the analysed economic and cultural context (see Ashcraft \& Blithe 2010; Startup Genome 2019, 2020). 
Another area of analysis that focuses on gender and startups is the owners motivations to start their business. In the case of men, starting their own business is caused by the pursuit of self-realization, and in the case of women, the effect of mediating between family (motherhood), personal, emotional and professional life (Marlow \& McAdam 2012; Paolini \& Dumai 2015).

An important area of research is the relationship between gender beliefs and expectations towards gender and the possibilities of obtaining funding for the operation of your own startup. Research Dana's Kanze, et al. (2018) show, that startups run by women are much less likely to receive funding from venture capitals funds, including due to the stereotypical assignment of gender-related characteristics to owners. During the public presentation of the idea of developed startups, women are much more often asked by investors about what actions they will take to resolve crisis situations, having to convince the audience that their invested capital will be returned. Men are obliged to prove in discussions how their startup will be successful and how the invested capital will bring profits (Kanze et al. 2018: 601-604). Such oriented questions, in a (startup) context in which the ability to take risks and maximize profits are rewarded, create specific perceptions about each gender and place women in a subordinate position at the stage of competition for financing (venture capitals) of their own business. The research by Ewens and Townsend (2020) also confirms the importance of gender stereotypes, showing that startups with the same specificity, run separately by women or men, are much less likely to obtain financing from male investors if their owner is a woman. The results of the above-mentioned studies are significant in the light of statistical data which show that in the USA (between 1990 and 2016), over 90\% of investors are men (Gompers \& Wang 2017). Ewens and Townsend observed that when the investor in a startup with female owner(s) is a different woman, these startups are more successful, than if the investor was a man (Ewensa \& Townsend 2020: $2)$. The reluctance of investors to finance startups run by women is puzzling in light of the data showing that these startups are characterized by a lower degree of debt and a slightly higher profitability (see Demartini 2018; Illuminate Ventures 2010). From the research of Loren Henderson et al. (2015) follows that startups owned by men also receive significantly higher credit scores than do new firms owned by women in the opinion of banks (Henderson et al. 2015: 477). It should be noted that startups run by women not only receive support from financial institutions less often, but also apply for it less often (Kwapisz \& Hechavarría 2018), which may be due to the awareness of the existing limitations.

Interestingly, also for the same reason as in the case of venture capitals funds, men are much less successful at crowdfunding (which is a form of financing various projects, based on small voluntary contributions from the community, deciding to support the project of its choice). Women starting their own business are considered to be more trustworthy than risk-oriented men, so they are more likely to receive the support of individual founders who are guided in their choices by gender stereotypes (Johnson, Stevenson, \& Letwin 2018: 826-827). This specific type of funding turns out to be more beneficial for women, because actors operating in this context follow the logic of credibility, and diminish the importance of competences. The results 
of research from the Swedish context confirm this general tendency and prove that women's startups are usually based on informal capital (Abbasian \& Yazdanfar 2015).

As writes Jeff Hearn, the still neglected area of empirical research conducted in the tradition of critical studies on men and masculinities (CSMM) are topics related to information and communication technologies, social media, artificial intelligence, robotics or, for example, big data (Hearn 2019: 58; see also Lohan \& Faulkner 2004). Importantly, these areas are the domain of many technology startups and institutions indirectly surrounding them.

Research conducted in the context of small IT companies proves that the discourse on masculinity in this industry (in Canada) normalizes youthfulness, short and intense character of individual careers, technological skills, contains numerous references to metaphors related to sport, war and "being motivated". In this context, aging means not so much age as fatigue with technical work, contributing to the departure of "veterans" from the industry (Comeau \& Camp 2007).

One of the few studies examining masculinity in intersectional terms in the context of Silicon Valley (see Shih 2006), describes strategies of Asian men (and women) in the workplace as representatives of minority groups. Johanna Shih emphasizes the importance of different contexts in developing paths of resistance, such as: alternative and rich networks, based on gender and ethnicity, improving the situation of marginalized individuals different from those dominated by older white men, and a dynamic labor market (Shih 2006: 200-202).

The article by Marianne Cooprer (2000) is another example of research that breaks the silence about masculinity as a cultural and social complex phenomenon, in which the author focuses on studying the identity of men who are employed in Silicon Valley and play the role of a father. Cooper shows that in the startup context, hegemonic masculinity gains a new character, it is based on specialist technical knowledge, many hours of work, leading to displaying verbal and physical exhaustion, thus proving his own commitment and endurance. The new hegemony diminishes the importance of physical strength and emphasizes the value of intellectual ability and resourcefulness. Work is performed in a "small team of great people", and is also a kind of youthful play, oriented to win (overcome competitors) in the market and bring profits (Cooper 2000: 381-387). According to Coooper, startups are characterized by "masculine ethic", because it is assumed that employees do not have obligations other than those resulting from paid work, thus hindering the implementation of the model of engaged paternity, practiced by “Superdads” (Cooper 2000: 394).

In summary, empirical research in the field of gender and technology startups is often quantitative, statistical, and aims to describe the "state" of the situation. The processual, discursive or symbolic dimensions of this type of organization are analyzed much less frequently. What is especially important, when gender is studied in the context of startups, many works focus mainly on women's experiences, "gender inequality" (see Wynn 2019) or "gender diversity" (see Kwapisz et al. 2014). Masculinity in startups, in the light of the available data, is usually captured in a one-dimensional and internally undifferentiated manner (e.g. the cited results of the works of Johnson et al. 2018; Kwapisz \& Hechavarría 2018; Kanze et al. 2018). And most of the existing 
research comes from highly developed countries, embracing the culture of the Global North (e.g. USA, Canada, UK, Sweden).

\section{GENDER THEORETICAL FRAMEWORK}

At the end of the $20^{\text {th }}$ century, a consensus developed on the basis of the discipline of gender studies, became the conviction that gender should be understood as a system that stratify social actors in intersectionally way (that is, intersects with various axes of inequality) and goes beyond individual properties (like gender identities, stereotypes, etc.) (Risman \& Davis 2013: 10). This system covers the level of organizational structures (see Gherardi \& Poggio 2001; Britton \& Logan 2008; Martin \& Collinson 2002; Avesson \& Billing 2009), which are gendered by the (often) invisible processes occurring within them that differentiate the status of women and men, as well as the applicable norms and logic of work, organizational culture and many other dimensions of the organization (Acker 2012, 1990, 2006). Which leads to the rooting and reproduction (in them) of a specific gender order and patterns (Connell 2006). According to Connell, gender patterns are active categories, they are not stable, and the relations between them are dynamic (Connell 2006: 838). In his classic typology, Connell distinguishes and defines four types of masculinity:

- hegemonic masculinity - characterized by heteronormativity, domination over women, children and other males, and the gender division of the labor market. For the remaining categories, it is a reference point, it can be embodied by few (Connell 2005: 77-78);

- complicit masculinity - which benefits from the gender order, although it does not achieve such a high status in society as hegemonic masculinity (Connell 2005: 79-80);

- subordinate masculinities - includes male patterns that, for various reasons, do not meet the conditions of the previous two patterns (for example, men of a non-heterosexual orientation) (Connell 2005: 78-79);

- marginalized masculinities - they refer to any relation of domination and subordination (between hegemonic and subordinate masculinities, or between subordinate masculinities) differentiated by social class or ethnic origin, and occurring in a specific context or (also in individual) situations (Connell 2005: 80-81).

The hegemonic status is the subject of constant struggle between different types of masculinity that can be embodied by individuals, groups or institutions (Connell 2005), and its content may undergo some changes (Connell 2003). However, the relative flexibility of the hegemonic pattern allows patriarchy to survive and reborn in different variations and socio-cultural contexts (Bridges \& Pascoe 2014: 247).

In recent years, other model of masculinity have also been discussed and developed. One of them is the concept of hybrid masculinity (Bridges and Pascoe 2014). The authors of the construct, convinced that there are currently significant changes in 
the gender order (based on the results of the analyses, see Messner 1993, 2007; Arxer 2011; Messerschmidt 2010) and conceptualize a new pattern that, according to them, is characterized by fluidity in integrating and distancing oneself from particular practices, typically ascribed to marginalized and subordinated patterns (Bridges \& Pascoe 2014: 247), with the assumption that this procedure, in a specific situational context, may bring benefits (Messner 2007: 461). The fragmentary borrowing of elements of practices or identities by persons with higher status makes gender inequalities much more difficult to identify than before (Messner 1993).

The literature on masculinities patterns also includes descriptions of inclusive masculinity (Anderson 2009; Anderson \& McCromack 2014 2018), mosaic masculinity (Coles 2008), or sticky masculinity (Berggren 2014). The last of the enumerated patterns is based on the author's deliberations on the discursive construction, negotiating the position of the subject, and drawing the attention of CSMM on an important aspect reproduction of masculine.

One of the paths of maintaining the gender order, the processes that legitimize it, and gender patterns are the discursive practices of individuals (Martin 2003; Connell 2006). Analyzing discourses and narratives allows one to learn about the dominant values and norms prevailing in cultures and organizations (Gherardi \& Poggio 2001; Gherardi 1996). The concept of gendered organizations, developed over the years, suggests that the values and norms dominating in organizations (also present in language) should be viewed as closely related to the cultural meanings assigned to genders (Acker 1992: 568). According to Acker, gender subtext, which in her understanding includes the written and spoken word, appearing in all explicit and implicit discursive organizational practices (documents, notes, guides and many others), become part of the organizational gender substructure (Acker 2012:217). Thus, the texts describing the methods of operation of an organization (both scientific and non-scientific) reproduce the gender patterns present in the organizational discourse (Bendl 2014), which, as I assume in this text, can be discovered by examining the discourse of reports informing about the state of startup organizations.

If we assume that male patterns are the result of a recursive relationship between the actors' individual identities and organizational structures (Risman 2004, 2011; Connell 2009), the structures of Polish startups, created in context of the information society and in line with the knowledge-based economy model, they can potentially be a space to engage in practices that construct patterns of masculinities with a new specificity. Moreover, recognizing the historicity, contextuality and situational character of gender (Connell 2006; Martin 2003; Ridgeway \& Correll 2004), the context of startup ecosystems in a developing economy, a country in Central and Eastern Europe, may also redefine the meanings attributed to e.g. hegemonic masculinity, and other gender types in relation to him. It is also worth paying attention to the fact that Polish startups, as a new type of organization, actual are created and developed in the period of strong transformations and social polarization (e.g. activism of ecological and feminist movements; technologization and digitization of processes inside companies; traditionalization and nationalization of public media discourse). The study patterns of masculine in such a specific social context that differs significantly from the insti- 
tutional and cultural environment of startups operating in the countries of the Global North (and from which a significant amount of research comes from) is the value of the analyses carried out in this paper.

\section{METHODOLOGY}

The purpose of this article is to examine and present what patterns of masculinities are present in the discourse of reports published by an institution describing the condition of Polish startups, and what characterized this identified patterns? For this purpose, I analyzed (1) practices to which startup employees are encouraged, (2) images (e.g. metaphors, symbols, values, ideas and icons) referred to in the discourse of reports, and (3) methods of presenting information and opinions in the examined documents. In the last part of my paper, I try to relate the results of my analyses to the specifics of the cultural and social context of Polish startups.

The research method that I used in my research was critical discourse analysis. The discourse itself in social sciences is defined in many ways, and for the purposes of this text, I understand the discourse as the entire act of communication, consisting of verbalization (text), but also a range of extra-linguistic factors, participants, accompanying situations of use, methods of production along with general psycho-socio-cultural context (Leszczyńska \& Skowronek 2010). Moreover, I also consider discourse as a tool for constructing reality, a means of reproducing ideology and power (Jabłońska 2006: 57). It is worth noting that masculinity as a construct (in Connell's theory) is entangled in relations with power and domination, as is the discourse, the critical analysis of which is to reveal the relations of subordination and privileging.

The meanings given to social actors and practices undertaken by them, I will interpret using gender interpretive frame, while at the same time relating them to the realities of the wider context in which the texts were created (gender order).

The selection of the sample was targeted choice and included all reports published by the "Startup Poland" Foundation from 2015 to 2019. In total, the collection of analyzed data included 5 reports, including four in Polish language and one (the last) in English language, with a total length of 437 pages. The Startup Poland Foundation ${ }^{1}$ is the only institution, which conducts regular research on the activities of startup organizations in Poland. The analyzed reports present the results of quantitative research and the number of respondents increased every year from 432 in 2015 to 1,235 in 2019. Report partners were both state (PARP) and private (Google, Citi Handlowy) units. All analyzed materials can be downloaded for free online ${ }^{2}$. The content of the

\footnotetext{
${ }^{1}$ In subsequent citations, appearing under the abbreviation "SP".

2 "Startup Poland. Raport 2015”: https://www.citibank.pl/poland/kronenberg/polish/files/Startup_Poland_raport 2015.pdf,

"Startup Poland. Raport 2016”: http://www.citi.com/poland/kronenberg/polish/files/Startup_Poland Raport_2016_16.pdf,

"Startup Poland. Raport 2017": http://www.citi.com/poland/kronenberg/polish/files/Startup_Poland raport 2017.pdf,

"Startup Poland. 2018”: http://citi.com/poland/kronenberg/polish/files/raport_startup_poland_2018.
} 
analyzed reports was encoded using the MAXQDA 2020. The encoding technique was based on the indicative encoding, after which the codes were merged into broader categories.

\section{RESULTS OF ANALYSES}

The purpose of the analysed reports, as the authors write in the 2019 publication, was: "First and foremost, the aim has been to make Poland and Polish startups more visible abroad and to overthrow all the stereotypes that have dogged Poland from the outset. Only when Poland appears as one of the strongest countries in CEE region can we drive the change and draw attention of foreign investors and capital to our market. The data that we collect is our weapon in this challenge, therefore every startup that took part in any of our researches has a real chance to influence Polish startup ecosystem on a bigger scale." (The Polish Tech Scene. 5 years, 2019: 12). The structure of the reports consisted of parts reporting the results of proprietary surveys, describing the characteristics of various dimensions of startup organizations and their environment. Usually, each section was provided with the statements and comments of experts. Men constituted the significant majority of specialists commenting on the situation of the Polish startup ecosystem. Each of the reports has a methodological part describing the method of conducted the research. This type of practice can be interpreted as a procedure aimed at authenticating the results and the validity of statements. Therefore, on the one hand, due to the research method used, these reports are partially scientific, on the other hand, due to experts statements - opinion-forming.

\section{Men in lens of critical analysis discourse}

Although it is not typical for discourse analysis to create numerical summaries, I decided to start by recalling purely statistical data to illustrate an important tendency that appears in results. In all analyzed reports, the concept of "man" appeared twice, and "male" - five times. The concept of a woman in its various possible variants (including also the English versions) appeared 46 times.

Looking quantitatively at the researched texts, masculinity and men, in the light of the analyses of reports, constitute an almost invisible category. Only in a few cases do they appear as a separately described phenomenon. Women, as a separate social category in startups, were described much more often and more precisely. However, this fact does not mean that there are no men among startup co-creators. The men in the reports are the silent, invisible majority. This is also evidenced by the statistics included in the report, which show that the number of management boards of all surveyed startups consisting exclusively of men ranged from $71.1 \%$ to $75.4 \%$ over the years. Masculinity and men function as "taken for granted" categories, that is, their presence in startups is widespread and does not need to be problematized. Being a

pdf,

“The Polish Tech Scene. 5 years” (2019): https://www.startups2019.startuppoland.org/. 
point of reference for other actors playing in the field, they constitute the background on the basis of which other elements of the startup ecosystem are listed.

In the first of the reports, to describe startups run by men and startups managed by mixed teams (women and men), the culturally related attributes of gender were referred to using the terms "skirts" and "slacks", emphasizing gender duality. Also, the headline "Skirts vs. slacks" signals their opposing and even competitive character. Although the authors summarize the differences between these two types of startups as "slight / insignificant" in the following, they are exposed by recalling the elements of clothing, as a gendered artefacts.

When analysing the discourse, the suggested procedure is to evaluate the content in the vicinity of which the topics of interest to us occur (Lisowska-Magdziarz 2007). In the reports of Startup Poland, among the distinguished characteristics, there were, among others being a woman, being a person from abroad, being a representative of the scientific community, as well as belonging to a given age group. Based on these elements, it is possible to describe a constellation of "background" traits: "non-feminine", "non-foreign" and "non-scientific" and age other than 20-40 years. Relating the content of the reports to the context in which they were created, we can interpret the majority as masculine, Polish, pragmatic / business / entrepreneurial and in (re) productive age.

Men, as a category in itself, have not been examined for internal complexity, unlike women, for whom a more detailed characterization has been taken. In one of the reports includes information about their marital status or the number of children:

More than half of the respondents admitted that they were in a relationship (for$\mathrm{mal}$ or informal) at the time of registering their business activity, and $45 \%$ of respondents already had children at that time. Every fourth woman, starting her career in business, was single, and about 1 in 8 raised a child (or children) alone. (SP 2017: 9)

There was no distinction between men into subcategories relating to family or personal life. The man presented in opposition to the feminine, and is object unrelated to the family, reproduction, or private life.

\section{Gendered categories in startup discourse}

Analysing the metaphors featured in the reports, startups can be interpreted in terms of an "child of entrepreneur" whose proper development is the main life goal of the "father". The text repeatedly contained phrases relating to a wide range of parenting experiences, such as: "incubator", "they were fledgling startups", or "stage of development". In the discourse of reports, startups are personified, they acquire human characteristics (like DNA), and are presented as a product of human procreation and creation of an entrepreneur, playing the role of a child in a symbolic space.

Each Partner's DNA has something that startup entrepreneurs need the most: capital, knowledge, energy and development. (SP 2017: 11)

The only examples of presenting masculinity in detail in the statistical results in- 
cluded in the report relate to business practices in startups run by men. It turns out that the organizations they manage less often use mentoring, more often act alone and sell to business customers, and produce "software" (SP 2015: 31). Masculinity is characterized only in the context of business and ways of cooperation. It is worth noting that directing your offer to business customers (not individual) and selling "software" are the strategies that bring the fastest profits. That means that male teams more often undertake practices thanks to which they gain access to key financial resources in this context.

Analysis of comments, relating to the practices undertaken by particular genders, showing men as persons who are less willing to admit their unawareness, taking advantage of other people's advice, or the guidance of experienced social actors. Masculinity is therefore the practice of striving for self-sufficiency and independence. In all reports, we can find multiple incentives directed towards startup owners, encouraging them to cooperate with various actors (scientists, investors, clients), create wide social networks, frequently use mentoring or appear at industry meetings. This context emphasizes the importance of networking, therefore the strategies undertaken by men in the dimension of social relations are not assessed positively.

Another feature that can be inferred from presupposition is the tendency to high or over-assess the value of one's own enterprise.

On the basis of the available data, however, we cannot state whether the higher valuations of "male" projects result from greater courage in estimates or the actual value of the company, especially since the declared revenue growth rate is only slightly higher in "slacks." (SP 2015: 32)

"Skirts", on the other hand, use mentoring much more often (or admit it more often!). (SP 2015: 32)

The credibility of the survey is based on the assumption that the declarations of our respondents are true. In the cases described above (presupposition), the authors suppose that "being a man" may be a factor "censoring" the answers, and therefore they assume caution in interpreting the obtained results. The fact that in 2015 the authors of the report were only women may also be significant. What has been attributed to masculinity in startups is not always an adequate belief about the value of one's own enterprise.

The analysis of the discourse of reports the Startup Poland foundation, showed that the language describing the desired values in such organizations is also gendered. One of the foundations of the activity of startup organizations is the desire to generate innovative solutions. The word - innovation - can be read in each of the reports from about 50 to 100 times, in its various varieties and contexts.

In the reports examined, innovation is perceived as something completely new, so far unprecedented, unique, but also transforming the current state of affairs. The opposite of this concept is "imitation". In the analysed texts, innovation has been associated with communication and information technologies, science, R\&D, ecosystems, the culture of innovation, globality, entrepreneurship or patenting solutions. 
The category of innovation in reports is both a feature of certain human practices or processes, but also a property assigned to specific solutions / inventions. Innovation in the startup ecosystem (regardless of which dimension it covers) is one of the key values that companies which want to achieve success should be oriented.

Every year, the Foundation's reports carefully monitored the number of people employed in Polish startups who were of different nationality. Startup owners were encouraged to hire foreigners in the comments of experts. In reports, cultural diversity implemented at the level of employee employment was presented as one of the strategies facilitating the generation of innovation. Argumentation proving its legitimacy was based on the indication of the possibility of reaping financial benefits and profits through access to a new source of competence and outlets along with an understanding of their specificity.

The benefits of employing foreign specialists are twofold - a startup not only gains competences, but also access to the network and insight into the needs of their markets of origin. In industries where the ability to flexibly respond to changing conditions is not only a virtue but also a necessity, a variety of points of view, methods of operation and environmental relations becomes an advantage. In a book store or a car repair shop, the benefits of international staff are generally not that visible - in a startup that makes its investment valuation dependent on the ability to expand abroad, this is a visible advantage. (SP 2017: 26)

Foreign specialists, in the network of connections takes the position of "gatekeepers", opening access to new capital and symbolic and cultural resources. Moreover, this opening offers a chance to gain a position of economic domination in a new field. Cultural diversity is thus becoming an idea "harnessed" to work for innovation.

Another motive that emerged in the discourse analysis was to encourage startups to "global expansion" and promote it as a desired state. All terms related to the expansion create a narrative in which entering foreign markets with your service is a symbol of victory, winning or achieving success.

This is especially true when serving enterprise clients; either you meet their demands for constant availability, responsive customer service, and constant expansion... Or you're left in the dust, overtaken by the competition. (SP 2019: 99)

The rhetoric of expansion it appeals to meanings with a colonial tinge, and brings to mind the economic conquest of new territories, increasing one's own sphere of influence, and places the startups actors in the position of conquerors.

In line with the startup dynamics, only a small percentage of projects will go through the entire process and reach the expansion phase. (SP 2017: 18)

This expansion also has its own individualistic variety. In the conducted analyses, it appears as an invitation to leave the "comfort zone", overcome oneself, cross the boundaries inherent in "only our heads" and be tireless in struggling with one's own weaknesses and encountered barriers.

If a company creates an organizational culture that highly values and cares about 
the needs of its employees, trusts them and gives them autonomy of action, creates an inspiring workplace where people have a chance for self-fulfilment, it will start attracting the best talents from Poland and the world. It will start ahead of the competition in terms of speed. It will delight customers and investors. It is then that the founder will begin the process of pushing the limits of development opportunities - first for his own, and then for his company. (SP 2017: 49)

The narrative appearing in the reports proves that not only the development of the organization depends on the acquisition of international talents, ahead of the competition and the delight of customers and investors, but also the development of the person who founded it. The structure of this argument suggest that the company is "extension" of its owner.

The founders are slowly learning to draw conclusions from their failures and set up new companies with the hope that this time it will succeed, because the point is not to give up. (SP 2016)

Doing startups is all about making mistakes. (SP 2017: 8)

Personal development is possible thanks to the method of trial and error. The attention of the recipients of the report is redirected from the effect to the very process of producing an innovative and powerful organization. Actors active in the startup ecosystem are encouraged to experiment, not to be discouraged by failures and to start new companies. Perseverance and dedication in pursuing a profitable and international company are presented as important values. However, this argument is inconsistent and may cause dissonance. On the one hand, the goal of all activities in the startup should be oriented towards scalability, expansion, cost reduction and innovation, ultimately leading to the generation of significant revenues. On the other hand, in a situation where work does not bring the intended profits, and the business model turns out to be a failure, the process is presented as valuable, not the effect (at which all activities have been directed so far).

Startups also mean a certain attitude and culture. Its fundamental values are openness, cooperation, ambition, growth, risk and dedication. It is the risk of failure, inherent in the nature of conducting startup experiments, that makes the spirit of unwavering, responsible entrepreneurship mature the fastest and most fully among startups. (SP 2017: 9)

A practice that startup owners are often encouraged to do, it is constant taking risk and brave decisions. For the effective development of startup ecosystems and enterprises, "strength of spirit" and "persistence" in achieving the set goals are equally important. Moreover, the value of these practices increases significantly when the narratives accompanying the goals pursued by companies, compared to improving the world, are taken into account.

Founders start from different positions, with unequal access to capital and the time they can spend on making their dreams come true, and not all have motivate improving the world. (SP 2016: 22) 
The discourse present in the reports creates a vision of the reality in which work becomes a path to self-improvement and self-development. In a comment by one of the experts, there is a comparison that indicates that finding and generating innovative solutions is like discovering cures for cancer. Although no one has succeeded in this so far, further attempts are still being made, the values of which are not questioned. If, however, any person were to engage in such an act, the health and soundness of his mind could be called into question by this argument.

Most research programs don't discover cures for cancer. However, no one in their right mind will give up funding research: because the very process of experimenting, as long as it is not secondary, is a value in itself and can bring beneficial, though unintended, results. (SP 2017: 9)

Searching for an antidote to cancer, which today is one of the most common causes of mortality, brings to mind the theme of salvation, redemption from misfortune and disease. More broadly, the language arguing the value of working in a startup is full of references to the vision of creating a better world, changing reality, and heroic actions. The advent of a better world may happen in this context by producing new solutions - mainly technological.

The images described above are complemented by numerous metaphors referring to the theme of combat in its various versions. One of them is the fight understood as an individual sport, then it takes place in the "ring", where the most important battles are fought for funding: "How many rounds of external financing have you used?" There are also references to team sports, where experts urge to build a team consisting of the best specialists from the beginning.

Another variant of combat is warfare / battle, in which the main goal is to recruit people who will help to "win" in the international "arena".

Companies cut a worthy piece of the market and defend it against the temptations of other players. (SP 2016: 68)

The language describing the context of startups actions present the many dangers which comes from the animal world, which can be seen through comparisons to the nature world (ecosystem, jungle, tigers, cockroaches, etc.)

However we still have a long way to go before we can talk with any degree of certainty about Polish entities of digital economy being tigers ready to emerge from the domestic jungle. (SP 2019: 100)

Actors of Polish startups are encouraged to engage in more aggressive practices, and surviving the most difficult periods in the startup's life cycle, referred to as "going through the valley of death".

During his visit to Warsaw, he paid special attention to the fact that we, Poles, must be more aggressive in promoting what we have. Customers from all over the world will not come alone, you have to hammer into them with doors and windows, but otherwise you cannot build a big business. Without aggressive promotion, we will never get the "Polish Skype." (SP 2016: 54) 
The metaphors used in the Foundation's reports, which create the reader's image of the described world, maintain the discourse of typical workers, which must prove physical strength, aggressiveness, and struggle.

\section{DISCUSSION}

The results of the analyses carried out confirm the tendency present in the literature on gender and startups, and show that the startup ecosystem is not a gender-neutral space. Gender in the reports of the Startup Poland Foundation is presented in a binary way, and masculinity and femininity are treated as opposing categories. Men, despite the fact that in all subgroups (investors, startup owners, experts) constitute a numerical majority in startups, their "direct" presence is distinguished only a few times, which makes them the background for events in the analysed context. This phenomenon has also been described in the literature so far as „invisible masculinity” (Kimmel 1993). While women were divided into certain subgroups (women who have / do not have children; who are / are not in partnerships), men constituted a monolithic, internally undifferentiated category, which is not related to the social networks of dependencies. Their non-professional needs, e.g. connected with family, are unnoticed, and the activity and agency of masculinity are present only in the public sphere, recreating the gender division of labour (procreation vs. reproduction) (Acker 1992). However, various studies show that men who take an active part in family life report a higher level of happiness and life satisfaction (Kimmel 2011: 164-191).

When analysing the gendered of the symbolic space of startup ecosystems, one can notice the presence of various patterns of masculinities, both in the structural and individual dimension.

On an individual level, startup employees are encouraged to practice hegemonic masculinity through numerous invitations to engage in fights, be aggressive, or compete, as well as show self-confidence to ultimately achieve winner status (on the market). The results of my research are consistent with the results of other studies, where masculinity in the technology industry was identified with self-confidence and the ability to achieve success (Wright 1996). As in the research by Cooper (2002) hegemonic masculinity in the context of startups, I gain a new quality, it is defined by commitment, persistence and stubbornness in carrying out specific tasks. In this context, the strength of physical muscles (associated with traditional masculinity) is exchanged for a force that internalizes and becomes a strength of spirit / personality strength. The linguistic layer contains many references to hegemonic masculinity, also through numerous comparisons of activities undertaken by actors, to behaviours present in sport, or to the vocabulary describing that context (see Kluczyńska 2010).

Actors in startup ecosystems are motivate to look for creative, non-schematic, "outof-box" solutions (usually from the field of technology), looking for inspiration and initiating actions that ultimately translate into profits. In this way, startup employees are obliged to constantly demonstrate and prove their worth, which corresponds to the dynamics of hegemonic masculinity, which as a status is transferable, and therefore must be confirmed by many practices (see Pacholok 2009). The logic of maximiz- 
ing profits and minimizing costs means that in new, Agile management models (like "Lean Startup", "Scrum"), the actors are subject to the performance regime.

In the startup ecosystem, through technocratism and the vision of work as a practice of heroic saving the world, cultural masculinity is spreading on a symbolic level.

Similarly, the category of "risk" can be read as gendered and put men and masculinities in a privileged position. The work model present in the startup (flexible working hours, no remuneration during the development period, non-standard forms of employment), on the one hand, may favor inclusiveness in the workplace (by activating people with caring roles in the family), on the other hand, has many points in common with the type of precarious work. However, the results of the research from the Polish context, shows that women more often choose stable work and long-term forms of employment, treating them as a source of a sense of security (Warat \& Krzaklewska 2016; Bhattacharya 2013). In startups, the feeling of uncertainty and responsibility for the risk taken is transferred to individual actors and their families. This model fits into the type of neoliberal economy, where the aim is to maximize market competitiveness, and work, due to factors such as uncertainty, lack of continuity of employment, limited level of protection or, for example, irregular remuneration - becomes a precarious one (Warat \& Krzaklewska 2016; see Patrick \& Elks 2015; Duell 2004; Kalleberg 2009). Due to cultural and biological conditioning but also specificity of work in startup, make them a space in which it is much easier to achieve success by practising the cultural patterns of masculinities described in the Connell concepts.

Statistics, referring to another important category for startups ecosystem, show that fields labeled “innovative” are mainly an area of men’s activity (see Młodożeniec \& Knapińska 2013; Glass et al. 2013). As mechanical force, computational rationality and technology experts (Lindberg 2012) dominate in the areas STEM, innovation has been permanently associated with hegemonic masculinity and their areas of activity. Authors such as Berglund and Thorslund (2012) believe that promoting men and certain forms of masculinity as the norm for innovation, and traditional male industries as places where they appear, minimizes the role of women and femininity by excluding them at work. As numerous studies show, the concept of innovation is strongly gendered, e.g. by creating a connotation between innovation and culturally understood masculinity (Blake \& Hanson 2005; Marlow \& McAdam 2012). Workplaces where actors are focused on caring, educating, and ensuring the durability of the social system, are much less often regarded as innovative. The effect of such a procedure is the exclusion of areas in which women have a numerical advantage and are the most active (e.g. education, health service, public sector) from innovation policy.

As already mentioned in the previous section, startups in the light of critical discourse analysis can be considered as an "extension" of an entrepreneur, while a number of terms describing activities undertaken in relation to startups refer to parental experiences. This thread can be interpreted in a differentiated way. On the one hand (taking into account the other elements of the discourse related to hegemonic masculinity and its patriarchal character), this narrative can be read as referring to the father archetype (which would symbolically strengthen the aforementioned male pattern). On the other hand, rhetoric in which there are threads of caring for a dependent start- 
up (because it is “crawling”, is in an "incubator”) may be associated with hybrid masculinity, or even with culturally understood traditional femininity. The correctness of such an interpretation may additionally be supported by numerous fragments that appear in the discourse, encouraging startups to show cooperation, create wide networks of social relations, or care for their employees. Startups can thus potentially constitute a space that favours the weakening of hegemonic masculinity in industries with a high degree of technology and facilitate the inclusion of previously marginalized groups. However, it should be taken into account that the authors of the concept of hybrid masculinity consider this construct rather as a new dynamics of relations between the genders, which, however, does not radically change the current gender order, but only reproduce systems of inequalities (Bridges \& Pascoe 2014: 247). Moreover, it obscures the specifics of existing hegemony, making current forms of domination much more difficult to grasp. In favour of this interpretation, there may be arguments present in the reports, where it is suggested to create new teams in order to gain a competitive advantage and knowledge of the "tacit" type, resulting from access to an understanding of the social context of potential customers.

The present and often mentioned in reports category of "expansion", directed towards foreign markets, and considered in a structural dimension, may be interpreted as an incentive to dominate the economic space, and the dominance itself is one of the other practices that constitute hegemony.

In an economy based on expansion and international cooperation, Polish startup organizations, due to the high degree of monoculturality of the country and the subordinate status of Poland in the system of global economic and political forces, encounter more difficulties in achieving hegemonic status, compared to the countries of the Global North (Connell 2014). When analysing the reports, it can be seen that this status is reserved for organizations such as: "Facebook", “Brainly.com”, "Apple”, "Twitter”, "eBay”, "Cisco Systems” and many others. Therefore, it seems more adequate to consider the relations between Polish startups (led mainly by men) and other actors playing in the field as relations embedded in the dynamics of complicit masculinity.

The results of the analyses showed that when we look at the discourse present in startups with sensitivity to gender issues, it turns out that this space, not only on the structural but also symbolic surface, is saturated with cultural patterns of masculinity that reinforce the gender order in a recursive and interconnected manner. Patterns of hegemonic masculinity are implemented by the biggest players in this field, i.e. companies that were startups in the past, and which over the years have achieved global success, usually measured by the company's stock exchange value. Practices that social actors are encouraged towards in startups often take on a partially hybrid nature, however, it cannot be clearly stated whether they strengthen or perhaps destabilize the current gender order.

The topics discussed in publication probably do not exhaust all the possibilities of interpreting and explaining gendered the content of the reports. In order to examine more closely the masculinity patterns present in the startup discourse, analyses focused on individual, in-depth interviews with startup members, but also analysing the 
content of formal documents (job advertisements, contracts, etc.), or the website of individual companies may turn out to be equally important. With reference to the postulates put forward by Ron Scollon (2001), it also seems valuable to undertake mediated discourse analysis, enriched with in-depth interviews and observations, in order to develop a much more holistic vision of the issues discussed. A valuable comparison would also be guaranteed by research on the non-discursive practices of social actors.

FUNDING: The article was written in preparation for participation in the NCN Preludium 19 competition. The final work on the text was carried out during the project "Innovative professional organizations: gender and technology startups.”, no. 2020/37/N/HS6/03913, and fit into the broader subject of research financed by the National Science Center in Poland, and focused on the analysis of gender patterns within technology startups.

CONFLICT OF INTEREST: The author declares no conflict of interest.

\section{REFERENCES}

Acker, Joan. 1990. "Hierarchies, jobs, bodies: A Theory of Gendered Organizations." Gender \& Society 4(2): 139-158. doi: 10.1177/089124390004002002

Acker, Joan. 1992. "From sex roles to gendered institutions." Contemporary sociology 21(5): 565-569. doi: $10.2307 / 2075528$

Acker, Joan. 2006. “Inequality regimes: Gender, class, and race in organizations.” Gender \& Society 20(4): 441-464. doi:10.1177/0891243206289499

Acker, Joan. 2012. "Gendered organizations and intersectionality: problems and possibilities, Equality, Diversity and Inclusion.” An International Journal 31(3): 214224. doi:10.1108/02610151211209072

Alsos, Agnete G., Elisabet Ljunggren, \& Ulla Hytti. 2013. "Gender and innovation: State of the art and a research agenda." International Journal of Gender and Entrepreneurship 5(3): 236-256. doi: 10.1108/IJGE-06-2013-0049

Alvesson, Mats \& Yvonne D. Billing. 1992. "Gender and Organization: Towards a Differentiated Understanding.” Organization Studies 13(1): 73-103. doi: $\underline{10.1177 / 017084069201300107}$

Alvesson, Mats \& Yvonne D. Billing. 2009. Understanding gender and organizations. London: Sage.

Anderson, Eric. 2009. Inclusive Masculinity. New York: Routledge.

Anderson, Eric \& Mark McCormack. 2018. "Inclusive masculinity theory: overview, refection and refinement." Journal of gender studies 27(5): 547-561. doi: $\underline{10.1080 / 09589236.2016 .1245605}$

Arxer, Steven. 2011. “Hybrid Masculine Power.” Humanity \& Society 35(4): 390-422. doi: $10.1177 / 016059761103500404$

Ashcraft, Catherine \& Sarah Blithe. 2010. Women in IT: The Facts. Colorado: Nation- 
al Center for Women \& Information Technology. Retrieved August 28, 2020 (https://www.ncwit.org/resources/women-it-facts).

Bendl, Regine. 2008. "Gender subtexts-reproduction of exclusion in organizational discourse." British Journal of Management 19: 50-64. doi: 10.1111/j.1467$\underline{8551.2008 .00571 . \mathrm{x}}$

Berggren, Kalle. 2014. "Sticky masculinity: Post-structuralism, phenomenology and subjectivity in critical studies on men." Men and Masculinities 17(3): 231-252. doi: $10.1177 / 1097184 X 14539510$

Berglund, Karin \& Jennie G. Thorslund. 2012. "Innovative policies? Entrepreneurship and innovation policy from a gender perspective.” Pp. 25-46 in Promoting innovation: Policies, practices and procedures, edited by S. Andersson, K. Berglund, E. Gunnarsson, \& E. Sundin. Stockholm: Vinnova.

Bhattacharya, Tithi. 2013. "Explaining gender violence in the neoliberal era." International Socialist Review 91: 2013-2014. Retrieved August 15, 2020 (https://isreview.org/issue/91/explaining-gender-violence-neoliberal-era).

Bird, Sharon R. \& Laura. A. Rhoton. 2011. “Women professionals' gender strategies: Negotiating gendered organizational barriers” Pp. 245-262 in Handbook of Gender, Work and Organization, edited by E. J. Leanes, D. Knights, \& P. Y. Martin. Chichester: Wiley: Blackwell.

Blake, Megan K. \& Susan Hanson. 2005. “Rethinking innovation: context and gender.” Environment and planning 37(4): 681-701. doi: 10.1068/a3710

Bridges, Tristan \& Cheri J. Pascoe. 2014. "Hybrid masculinities: New directions in the sociology of men and masculinities." Sociology Compass 8(3): 246-258. doi: 10.1111/soc4.12134

Britton, Dana M. \& Laura Logan. 2008. "Gendered organizations: Progress and prospects.” Sociology Compass 2(1): 107-121. doi: 10.1111/j.1751-9020.2007.00071.x

Coles, Tony. 2008. "Finding space in the field of masculinity: Lived experiences of men's masculinities." Journal of Sociology 44(3): 233-248. doi: $10.1177 / 1440783308092882$

Comeau, Tammy D. \& Candace L. Kemp. 2007. "Intersections of age and masculinities in the information technology industry.” Ageing and Society 27: 215-232. doi: 10.1017/S0144686X06005605.

Connell, Raewyn W. 2003. "Developing a theory of gender as practice: Notes on Yancey Martin's feminist lecture.” Gender \& Society 17(3): 370-372. doi: $10.1177 / 0891243203017003004$

Connell, Raewyn W. 2005. Masculinities. $2^{\text {th }}$ ed. Cambridge: Polity.

Connell, Raewyn W. 2006. "Glass ceilings or gendered institutions? Mapping the gender regimes of public sector worksites." Public administration review 66(6): 837849. doi: 10.1111/j.1540-6210.2006.00652.x

Connell, Raewyn W. 2009. Gender in World Perspective. Cambridge: Polity.

Cooper, Marianne. 2000. "Being the "go-to guy": Fatherhood, masculinity, and the organization of work in Silicon Valley.” Qualitative Sociology 23(4): 379-405. doi: 10.1023/A:1005522707921

Demartini, Paola. 2018. "Innovative female-led startups. Do women in business un- 
derperform?” Administrative Sciences 8(4): 70. doi: 10.3390/admsci8040070

Duell, Nicola. 2004. Defining and assessing precarious employment in Europe: a review of main studies and surveys. Munich: ESOPE Project.

Epstein, Cynthia F. 1988. Deceptive distinctions: Sex, gender, and the social order. Yale University Press.

Ewens, Michael \& Richard R. Townsend. 2020 “Are early stage investors biased against women?” Journal of Financial Economics 135(3): 653-677. doi: 10.1016/j.jfineco.2019.07.002

Gherardi, Silvia. 1996. "Gendered organizational cultures: narratives of women travellers in a male world.” Gender, Work \& Organization 3(4): 187-201. doi: 10.1111/ j.1468-0432.1996.tb00059.x

Gherardi, Silvia \& Barbara Poggio. 2001. "Creating and recreating gender order in organizations." Journal of world business 36(3): 245-259. doi: 10.1016/S10909516(01)00054-2

Glass, Jennifer L., Sassler Sharon, Levitte Yael, \& Katherine M. Michelmore. 2013. "What's So Special about STEM? A Comparison of Women's Retention in STEM and Professional Occupations." Social forces 92(2): 723-756. doi: 10.1093/sf/ $\underline{\text { sot092 }}$

Gompers, Paul A. \& Sophie Q. Wang. 2017. Diversity in innovation. Cambridge: National Bureau of Economic Research.

Hearn, Jeff. 2019. "So what has been, is, and might be going on in studying men and masculinities?: Some continuities and discontinuities". Men and Masculinities 22(1): 53-63. doi: 10.1177/1097184X18805550

Henderson, Loren, Herring Cedric, Horton D. Hayward, \& Thomas Melvin. 2015. “Credit Where Credit is Due?: Race, Gender, and Discrimination in the Credit Scores of Business Startups.” The Review of Black Political Economy 42(4): 459-479. doi: 10.1007/s12114-015-9215-4

Illuminate Ventures. 2010. High Performance Entrepreneurs Women in High Tech. Retrieved March 28, 2015 (http://www.illuminate.com/whitepaper/).

Jabłońska, Barbara. 2006. „Krytyczna analiza dyskursu: refleksje teoretyczno-metodologiczne." Przegląd Socjologii Jakościowej 2(1): 53-67. Retrieved June 15, 2020 (http://www.qualitativesociologyreview.org/PL/archive_pl.php).

Johnson, Michael A., Regan M. Stevenson, \& Chaim R. Letwin. 2018. “A woman's place is in the... startup! Crowdfunder judgments, implicit bias, and the stereotype content model." Journal of Business Venturing 33(6): 813-831. doi: 10.1016/j. jbusvent.2018.04.003

Kalleberg, Arne L. 2009. "Precarious Work, Insecure Workers: Employment Relations in Transition." American Sociological Review 74(1): 1-22. doi: 10.1177/000312240907400101

Kanter, Moss R. 1977. Men and Women of the Corporation. New York: Basic Books.

Kanze, Dana, Huang Laura, Conley Mark A., \& Tory E. Higgins. 2018. “We ask men to win and women not to lose: Closing the gender gap in startup funding." Academy of Management Journal 61(2): 586-614. doi: 10.5465/amj.2016.1215

Kimmel, Michael. 1993. “Invisible Masculinity.” Society 30(6): 28-35. doi: 10.1007/ 
BF02700272

Kimmel, Michael. 2011. The Gendered Society. $4^{\text {th }}$ ed. Oxford: Oxford University Press. Kluczyńska, Urszula. 2010. „Sport jako obszar konstruowania tożsamości mężczyzn. Znaczenia wpisane w sport i możliwości ich definiowania.” Pp. 86-99 in Męskość jako kategoria kulturowa, edited by M. Dąbrowska \& A. Radomski. Lublin: Wydawnictwo Portalu Wiedza i Edukacja.

Kulej, Agnieszka. 2018. „Atrybuty start-upów jako podmiotów o charakterze innowacyjny.” Zeszyty Naukowe Politechniki Częstochowskiej 31: 145-153. doi: 10.17512/ znpcz.2018.3.12

Kwapisz, Agnieszka \& Diana M. Hechavarría. 2018. “Women don’t ask: an investigation of start-up financing and gender." Venture Capital 20(2): 159-190. doi: $10.1080 / 13691066.2017 .1345119$

Kwapisz, Agnieszka, Bryant Scott, \& Brent Rosso. 2014. "Should Men and Women Start Companies Together? The Impact of Team Diversity on Startup Success.” Academy of Management Proceedings No. 1. doi: 10.5465/AMBPP.2014.17252abstract

Leszczyńska, Katarzyna. 2016. Płeć w instytucje uwikłana. Warszawa: Wydawnictwo Naukowe Scholar.

Leszczyńska, Katarzyna \& Katarzyna Skowronek. 2010. „Socjologia języka / socjolingwistyka a społeczna analiza dyskursu. Perspektywa socjologa i językoznawcy.” Socjolingwistyka 24: 7-28.

Lindberg, Malin. 2012. "A striking pattern: Co-construction of innovation, men and masculinity in Sweden's innovation policy.” Pp. 47-67 in Promoting innovation: Policies, Practices and Procedures, edited by M. Lindberg. Stockholm: Vinnova.

Lisowska-Magdziarz, Małgorzata. 2007. Analiza tekstu w dyskursie medialnym. Przewodnik dla studentów. Kraków: Wydawnictwo UJ.

Lohan, Maria \& Wendy Faulkner. 2004. "Masculinities and technologies: Some introductory remarks." Men and masculinities 6(4): 319-329. doi: $10.1177 / 1097184$ X03260956

Marlow, Susan \& Maura Mcadam. 2012. “Analyzing the influence of gender upon hightechnology venturing within the context of business incubation." Entrepreneurship Theory and Practice 36(4): 655-676. doi: 10.1111/j.1540-6520.2010.00431.x

Martin, Patricia Y. \& David Collinson. 2002. “Over the pond and across the water': developing the field of 'gendered organizations." Gender, Work \& Organization 9(3): 244-265. doi: 10.1111/1468-0432.00159

Martin, Patricia. 2003. "Said and done' versus 'saying and doing': Gendering practices, practicing gender at work.” Gender \& Society 17: 342-366. doi: 10.1177/0891243203017003002

McCormack, Mark \& Eric Anderson. 2014. "Homohysteria: Definitions, context and intersectionality." Sex Roles 71(3-4): 152-158. doi: 10.1007/s11199-014-0401-9

Messerschmidt, James. 2010. Hegemonic Masculinities and Camouflaged Politics. Boulder: Paradigm Publishers.

Messner, Michael. 1993. "”Changing Men” and Feminist Politics in the United States." Theory and Society 22(5): 723-737. doi: 10.1007/BF00993545.

Messner, Michael. 2007. “The Masculinity of the Governator.” Gender \& Society 21(4): 
461-80. doi: $10.1177 / 0891243207303166$

Młodożeniec, Marek \& Anna Knapińska. 2013. „Czy nauka wciąż ma męską płeć? Udział kobiet w nauce." Nauka 2: 47-72.

Pacholok, Shelley. 2009. "Gendered strategies of self: Navigating hierarchy and contesting masculinities.” Gender, Work \& Organization 16(4): 471-500. doi: 10.1111/j.1468-0432.2009.00452.x

Paoloni, Paola \& John Dumay. 2015. "The relational capital of micro-enterprises run by women: The startup phase.” Vine 45(2): 72-197. doi: 10.1108/VINE-01-2014$\underline{0003}$

Patrick, Holly \& Kate Elks. 2015. “From Battery Hens to Chicken Feed: The Perceived Precarity and Identity of Australian Journalists.” Asia Pacific Journal of Arts and Cultural Management 12(1): 48-66.

Ridgeway, Cecilia L. \& Shelley J. Correll. 2004. “Unpacking the gender system: A theoretical perspective on gender beliefs and social relations." Gender \& Society 18(4): 510-531. doi: $10.1177 / 0891243204265269$

Risman, Barbara J. 2004. "Gender as a social structure: Theory wrestling with activism.” Gender \& Society 18(4): 429-450. doi: 10.1177/0891243204265349

Risman, Barbara J. 2011. “Gender as structure or trump card?” Journal of Family Theory \& Review 3(1): 18-22. doi: 10.1111/j.1756-2589.2010.00076.x

Risman, Barbara J. \& Georgiann Davis. 2013. “From sex roles to gender structure.” Current Sociology 61(5-6): 733-755. doi: 10.1177/0011392113479315

Scollon, Ron. 2001. “Action and text: towards an integrated understanding of the place of text in social (inter) action, mediated discourse analysis and the problem of social action.” Pp. 139-183 in Methods of critical discourse analysis. Vol. 113, edited by R. Wodak \& M. Meyer. London: Sage.

Shih, Johanna. 2006. "Circumventing discrimination: Gender and ethnic strategies in Silicon Valley.” Gender \& Society 20(2): 177-206. doi: 10.1177/0891243205285474

Siemieńska, Renata, ed. 2019. Kariery akademickie kobiet i mężczyzn. Różne czy podobne? Warszawa: Wydawnictwo Naukowe Scholar.

Startup Genome. 2019. Global Startup Ecosystem Report 2019. Retrieved August 5, 2019 (https://startupgenome.com/reports/gser2020).

Startup Genome. 2020. Global Startup Ecosystem Report 2020. Retrieved August 5, 2020 (https://startupgenome.com/reports/gser2020).

Warat, Marta \& Ewa Krzaklewska. 2016. „Czy prekariat ma płeć? Sytuacja kobiet i mężczyzn na rynku pracy w Polsce.” Rocznik Lubuski 42(1): 229-245.

Williams, Mary L., Charles Waldauer, \& Vijaya G. Duggal. 1992. "Gender differences in economic knowledge: An extension of the analysis." The Journal of Economic Education 23(3): 219-231. doi: 10.1080/00220485.1992.10844756

Wynn, Alison T. 2019. "Pathways toward change: ideologies and gender equality in a Silicon Valley technology company.” Gender \& Society 34(1)” 106-130. doi: $10.1177 / 0891243219876271$

Yazdanfar, Darush \& Saeid Abbasian. 2015. "Gender and the use of external business advice: a Swedish study." International Journal of Gender and Entrepreneurship 7(1): 105-124. doi: 10.1108/IJGE-05-2014-0016 


\section{ANALYZED REPORTS}

Kruczkowska, Eliza, Magdalena A. Olczak, \& Agnieszka Skala. 2015. Startup Poland. Raport 2015. Retrieved March 15, 2020 (https://www.citibank.pl/poland/kronenberg/polish/files/Startup_Poland_raport_2015.pdf).

Kruczkowska, Eliza \& Agnieszka Skala. 2016. Startup Poland. Raport 2016. Retrieved March 15, 2020 (http://www.citi.com/poland/kronenberg/polish/files/Startup Poland_Raport_2016_16.pdf).

Beauchamp, Magdalena, Agata Kowalczyk, Agnieszka Skala, \& Tomasz Ociepka. 2017. Startup Poland. Raport 2017. Retrieved March 15, 2020 (http://www.citi.com/poland/kronenberg/polish/files/Startup_Poland_raport_2017.pdf).

Beauchamp, Magdalena, Julia Krysztofiak-Szopa, Tomasz Ociepka, \& Agnieszka Skala. 2018. Startup Poland. 2018. Retrieved March 15, 2020 (http://citi.com/poland/ kronenberg/polish/files/raport_startup_poland_2018.pdf).

Krysztofak-Szopa, Julia \& Monika Wisłowska. 2019. The Polish Tech Scene. 5 years. Retrieved March 15, 2020 (https://www.startups2019.startuppoland.org/).

\section{BIOGRAPHICAL NOTE}

Edyta Tobiasiewicz is a PhD student at the Institute of Sociology of the Jagiellonian University. She is interested in gender sociology as well as in the sociology of organization and innovation. Currently, she is conducting research within the grant "Preludium-19", entitled Innovative professional organizations: gender and technology startups.

OPEN ACCESS: This article is distributed under the terms of the Creative Commons Attribution Non-commercial License (CC BY-NC 4.0) which permits any non-commercial use, and reproduction in any medium, provided the original author(s) and source are credited.

ARTICLE HISTORY: Received 2020-09-07 / Accepted 2020-03-01 